\title{
ENCLAVES DE URBANIDADE: A ATUAÇÃO DO MERCADO IMOBILIÁRIO NA RECENTE OCUPAÇÃO DA RODOVIA BA-001, TRECHO ILHÉUS- OLIVENÇA

\author{
URBANITY ENCLAVES: THE PERFORMANCE OF THE REAL ESTATE MARKET IN THE RECENT OCCUPATION \\ OF HIGHWAY BA-001, SECTION ILHÉUS-OLIVENÇA
}

\author{
Karina Fernanda Travagim Viturino Neves ${ }^{1}$ \\ ${ }^{1}$ Instituto Federal da Bahia (IFBA), Salvador, BA, Brasil
}

\author{
Correspondência para: Karina Fernanda Travagim Viturino Neves (kftvneves@yahoo.com.br) \\ doi: 10.12957/geouerj.2018. 21903 \\ Recebido em: 08 mar. 2016 | Aceito em: 23 nov. 2018
}

\section{SCREENED BY iThenticate}

\section{RESUMO}

A região conhecida como Sul da Bahia foi tradicionalmente dedicada ao cultivo do cacau até que uma grave crise atingiu essa monocultura no final do século XX. Desde então verificamos uma reorganização das atividades econômicas, com a inserção de novas lógicas de apropriação do espaço. Esse artigo reúne os resultados de uma pesquisa geográfica desenvolvida com o objetivo de caracterizar e discutir questões envolvidas na recente ocupação da Zona Sul do município de Ilhéus, no qual analisamos a expressiva atuação do mercado imobiliário e as recentes transformações na Rodovia Ilhéus-Olivença (BA-001). Apesar de ser considerada pelo poder público como área prioritária para o desenvolvimento do turismo e para expansão urbana do município de Ilhéus a área de estudo pode ser classificada como área rural. Mesmo assim, as margens dessa rodovia Ilhéus-Olivença foram tomadas por empreendimentos imobiliários de médio e alto padrão. Graças à atuação do mercado imobiliário que investe em infraestrutura e explora os atributos de localização - sobretudo a proximidade com o mar verificamos a intensificação da ocupação dessa área a partir do ano de 2010.

Palavras-chave: Apropriação do espaço. Mercado imobiliário. Cidades médias. Rodovia Ilhéus-Olivença (BA-001). Enclaves de urbanidade.

\section{ABSTRACT}

The region known as Southern Bahia was traditionally dedicated to the cultivation of cocoa until a serious crisis reached this monoculture at the end of the 20th century. Since then we have verified a reorganization of economic activities, with the insertion of new logics of appropriation of space. This article brings together the results of a geographic survey developed with the objective of characterizing and discussing issues involved in the recent occupation of the South Zone of the municipality of Ilhéus, in which we analyze the significant performance of the real estate market and the recent transformations in the Ilhéus-Olivença Highway (BA -001). Despite being considered by the government as a priority area for the development of tourism and for urban expansion of the municipality of Ilhéus, the study area can be classified as a rural area. Even so, the banks of this highway Ilhéus-Olivença were taken by real estate projects of medium and high standard. Thanks to the activity of the real estate market that invests in infrastructure and exploits the attributes of location - especially the proximity to the sea - we verified the intensification of the occupation of this area from the year 2010.

Keywords: Appropriation of space. Real estate market. Medium cities. Highway Ilhéus-Olivença (BA-001). Enclaves of urbanity.

\section{INTRODUÇÃO}

Desde meados de 1890 a monocultura do cacau se firmou como principal atividade econômica do Sul da Bahia, projetando essa região no cenário nacional e internacional devido à grande riqueza 
proveniente da comercialização das amêndoas do fruto. De acordo com o Instituto Brasileiro de Geografia e Estatística (IBGE), a mesorregião Sul Baiano compreende três microrregiões: Valença, Ilhéus-Itabuna e Porto Seguro e embora atualmente essas microrregiões se diferenciem econômica e culturalmente, elas estiveram por muito tempo integradas pela produção cacaueira.

A partir do ano de 1989, uma grave crise atingiu o Sul da Bahia, impactando de forma significativa a monocultura cacaueira e provocando importantes transformações socioespaciais. O senso comum tende a associar essa crise à doença vulgarmente denominada vassoura-de-bruxa - doença provocada pelo fungo Crinipellis perniciosa, que se alastra pelo vento contaminando as plantas, inutilizando os frutos e provocando reduções drásticas na produtividade e consequentemente nos ganhos oriundos da atividade. No entanto, a dita crise da vassoura-de-bruxa não pode ser compreendida apenas por meio da análise da disseminação dessa doença e seus impactos na produção cacaueira.

Chiapetti (2009) analisa a instauração dessa crise a partir da ocorrência de cinco eventos simultâneos e inter-relacionados observados a partir de 1980, quais sejam: a) a diminuição dos preços do cacau no mercado internacional; b) a conjuntura político-econômica mundial doravante orientadas pelos princípios neoliberais e seus reflexos na conjuntura política nacional; c) um longo período de seca que se estendeu de 1987 a 1992; d) o aparecimento da vassoura-de-bruxa; e e) modificações na estrutura global de oferta.

É fato, investigado por vários pesquisadores (BAIARDI, 1984; ROCHA, 2008; CHIAPETTI, 2009; NOIA, MIDLEJ \& ROMANO, 2015 dentre outros) que o cultivo do cacau no Sul da Bahia desenvolveu-se sob crises cíclicas; e é consenso que a crise iniciada em 1989 é a pior da história sulbaiana.

Quando da deflagração da crise da vassoura-de-bruxa a produtividade do cacau no Sul da Bahia decaiu significativamente - atingindo patamares que indicam redução de cerca de $40 \%$ - pois conforme explicam Cuenca e Nazário (2004, p. 14) "Essa doença espalhou-se por toda a Região Sul da Bahia, trazendo prejuízo e desânimo entre os produtores, fazendo cair a produção de 400 mil toneladas, em 1990, para 174 mil toneladas em 2003”. 
Com a persistência da crise nas décadas que se seguiram, verificamos a progressiva diminuição do território do cacau: em seu auge, em 1992, chegou a englobar 83 municípios baianos de 8 microrregiões distintas e, pela análise de dados mais recentes o território do cacau na Bahia seria composto por 35 municípios, sendo 27 deles pertencentes à microrregião Ilhéus-Itabuna (NEVES, 2018).

Nesse contexto de crise da atividade cacaueira a busca por alternativas levou à reorganização das atividades econômicas em âmbito regional e conduziu as três microrregiões sul-baianas por caminhos independentes. A atividade cacaueira foi progressivamente abandonada nas microrregiões de Porto Seguro e Valença e mesmo na microrregião Ilhéus-Itabuna onde essa atividade ainda é significativa o contexto de crise do cacau possibilitou a emergência de novas lógicas de apropriação do espaço, dentre elas, o franco desenvolvimento do mercado imobiliário que é o tema de investigação desse estudo.

O desenvolvimento desse trabalho se deu a partir das atividades do Núcleo de Estudos Urbanos e Culturais do Sul da Bahia (NEPUC-SB) - eixo Ilhéus-Itabuna, do Instituto Federal de Educação, Ciência e Tecnologia da Bahia (IFBA/Campus Ilhéus) - que desde 2014 tem se dedicado a identificar, mapear e compreender as transformações em curso em nossa microrregião.

Os estudos desenvolvidos pelo NEPUC-SB indicam que as transformações observadas no sul da Bahia pós-crise da vassoura-de-bruxa podem ser agrupadas em dois ciclos: 1989-2000 e pós-2000. 0 primeiro ciclo de transformações, já bastante estudado no meio acadêmico, seria concomitante à crise iniciada em 1989 e seria caracterizado pela lenta, porém contínua diversificação de atividades econômicas na região, diversificação essa conduzida majoritariamente pelo Estado, sobretudo em suas instâncias municipal e estadual ao fomentar novas atividades como forma de recuperação da economia. Especificamente no eixo Ilhéus-Itabuna, durante esse primeiro ciclo de transformações, identificamos o desenvolvimento de indústrias, comércio e serviços, sendo que as ações empreendidas pelo Estado acabaram consolidando uma rede urbana (TRINDADE, 2015) na qual Itabuna se firmou 
regionalmente como polo comercial enquanto Ilhéus, por sua condição litorânea, passou a investir na atividade turística ${ }^{1}$.

Avaliamos que a progressiva perda de importância econômica do cacau no Sul da Bahia associada à consolidação de novas atividades em escala local atraiu, a partir dos anos 2000, novos agentes que passaram a intervir sobretudo nos dois principais municípios - Ilhéus e Itabuna - imprimindo novas lógicas e dinâmicas de apropriação do espaço doravante hegemônicas e, não raro, generalizadas para outras cidades do Sul da Bahia.

Conforme nos explica Santos (2009)

Os conjuntos formados por objetos novos e ações novas tendem a ser mais produtivos e constituem, num dado lugar, situações hegemônicas. Os novos sistemas de objetos põem-se à disposição das forças sociais mais poderosas, quando não deliberadamente produzidos para seu exercício. Ações novas podem dar-se sobre velhos objetos, mas sua eficácia é, assim, limitada (SANTOS, 2009, p. 97).

Tomando como referência o segundo ciclo de transformações (pós-2000) identificamos nas duas principais cidades do eixo Ilhéus-Itabuna tanto a aceleração da implantação de novos objetos e novas ações quanto a refuncionalização de velhos objetos - aqueles decorrentes de materializações de outros tempos históricos. Com isso, a importância histórica das duas cidades que nomeiam a microrregião central do Sul da Bahia se reafirma no contexto atual como explica Trindade (2015).

\footnotetext{
Alguns fluxos relacionados à cacauicultura desapareceram e fluxos de outras naturezas emergiram em decorrência das atividades produtivas surgidas ou aprimoradas. Se as interações entre Itabuna-Ilhéus e as demais cidades da rede regional foram mantidas em um nível de interdependência que continua privilegiando os dois centros regionais em detrimento das pequenas cidades, isto significa que os laços engendrados pela cacauicultura foram tão bem atados que, mesmo após tantas transformações, continuam mantendo hierarquias difíceis de serem superadas (TRINDADE, 2015, p. 155).
}

Reconhecendo que novas lógicas e dinâmicas de apropriação do espaço passaram a se desenvolver nesses dois municípios os estudos do NEPUC-SB passaram a se concentrar nesse segundo ciclo de transformações e identificaram como principais agentes de transformação regional o Estado ${ }^{2}$ e 0 mercado imobiliário.

\footnotetext{
${ }^{1} \mathrm{O}$ turismo, aliás, passou a ser uma importante atividade econômica das três microrregiões do Sul Baiano a partir da década de 90 - ainda que praticamente restrita aos municípios litorâneos (SILVA et. al., 2004).

${ }^{2}$ No que se refere à atuação do Estado em âmbito regional destacamos as grandes obras públicas já concluídas, a exemplo do Instituto Federal da Bahia (IFBA), Universidade Federal do Sul da Bahia (UFSB), Hospital Regional da Costa do Cacau,
} 
A pesquisa que ora apresentamos nesse artigo se desenvolveu a partir da investigação da Zona Sul do município de Ilhéus, definida como uma das áreas prioritárias de estudo pelo NEPUC-SB por apresentar significativas mudanças nos últimos anos, fruto da valorização dos imóveis, multiplicação de empreendimentos imobiliários e do incremento populacional.

Especificamente para essa pesquisa definimos a seguinte questão: "Quais são os elementos que podem explicar o crescente interesse imobiliário na Zona Sul do município de Ilhéus particularmente em áreas afastadas, carentes de serviços públicos e equipamentos urbanos?" e orientamos nosso estudo para alcançar o objetivo geral de "Caracterizar e discutir questões envolvidas na recente ocupação da Zona Sul do município de Ilhéus".

Para tanto, definimos como objetivos específicos: a) compreender o processo de ocupação do trecho que liga o município de Ilhéus ao distrito de Olivença procurando diferenciar as lógicas de apropriação do espaço em tempos distintos; b) investigar a atuação do mercado imobiliário em cidades médias procurando compreender a recente valorização de imóveis nessa área de estudo; c) analisar os principais impactos decorrentes das novas lógicas de ocupação da área de estudo.

O estudo se desenvolveu a partir dos registros de um longo período de observação estruturada (20102018) complementados por pesquisa bibliográfica e pesquisa de campo e envolveu os seguintes procedimentos metodológicos: observação estruturada e registro escrito; análise de textos, documentos, reportagens, materiais publicitários e de divulgação provenientes do setor imobiliário; registro fotográfico; identificação, localização e mapeamento de empreendimentos imobiliários de médio e alto padrão; consultas periódicas a empresas imobiliárias; entrevistas com agentes imobiliários, trabalhadores atuantes na área de estudo e moradores locais.

Investigando o tema a partir das peculiaridades de ação do mercado imobiliário em cidades médias e analisando o estudo de caso sob a ótica das relações cidade-campo, nosso estudo apontou que mesmo diante da forte atuação do mercado imobiliário nos últimos anos e da tendência à atração de grandes 
contingentes populacionais a curto e médio prazo, a área de estudo poderia ser caracterizada pela precariedade no tange o acesso a serviços públicos e equipamentos urbanos.

A recente ocupação do trecho da Rodovia BA-001 que liga Ilhéus à Olivença parece estar atrelada direta e indiretamente - aos inúmeros empreendimentos imobiliários de médio e alto padrão que, reconhecendo as dificuldades de habitar essa área, investem em infraestrutura, segurança e equipamentos de lazer ao mesmo tempo em que exploram os atributos naturais e turísticos da Zona Sul.

Dividimos os resultados de pesquisa em 3 segmentos. No primeiro, intitulado "Entre o urbano e o rural: caracterização da Rodovia BA-001 no trecho entre Ilhéus e Olivença” apresentamos a área de estudo e a problemática de desenvolvimento da pesquisa. No segundo segmento "De point turístico à local de moradia: precariedade X marketing imobiliário" investigamos o contexto de desenvolvimento do turismo no município de Ilhéus e analisamos o histórico de ocupação dessa área. Por fim, no terceiro e último segmento denominado "Mercado imobiliário em cidades médias: o estudo de caso da recente ocupação da Rodovia Ilhéus-Olivença (BA-001)" discutimos a atuação do mercado imobiliário em cidades médias e identificamos os principais empreendimentos que têm intensificado a ocupação dessa área que concentra os principais investimentos imobiliários de alto e médio padrão no município de Ilhéus.

\section{Entre o urbano e o rural: caracterização da Rodovia BA-001 no trecho entre Ilhéus e Olivença}

Conforme indicamos, o estudo apresentado nesse artigo integra as atividades do NEPUC-SB porém essa área é objeto de investigação da autora desde o final do ano de 2010, quando a mesma passou a habitar um loteamento no $\mathrm{Km} 10$ do referido trecho da rodovia e passou a reunir sistematicamente informações sobre: a) o zoneamento municipal e a classificação da área de estudo; b) os principais lançamentos imobiliários às margens da rodovia; c) a variação de preços de imóveis na área de estudo e d) tópicos relacionados à disponibilidade/acesso a serviços e equipamentos urbanos em diferentes trechos da rodovia, entre outros. 
Ao participar do projeto de pesquisa "Transformações na paisagem do Sul da Bahia: lógicas e dinâmicas de apropriação do espaço" desenvolvido no período de 2014-2017 pelo NEPUC-SB, a pesquisadora defendeu a inclusão desse trecho da Rodovia BA-001 ${ }^{3}$ que liga Ilhéus ao distrito de Olivença (Figura 1) entre as áreas prioritárias de investigação do núcleo, por compreender que esse consiste num caso emblemático para o estudo da apropriação do espaço pelo mercado imobiliário pois, embora o setor da construção civil tenha apresentado franco desenvolvimento no município como um todo a partir dos anos 2000 é essa área que tem apresentado maior dinamismo do setor concentrando, a partir de 2010, grande parte dos lançamentos imobiliários de médio e alto padrão ${ }^{4}$.
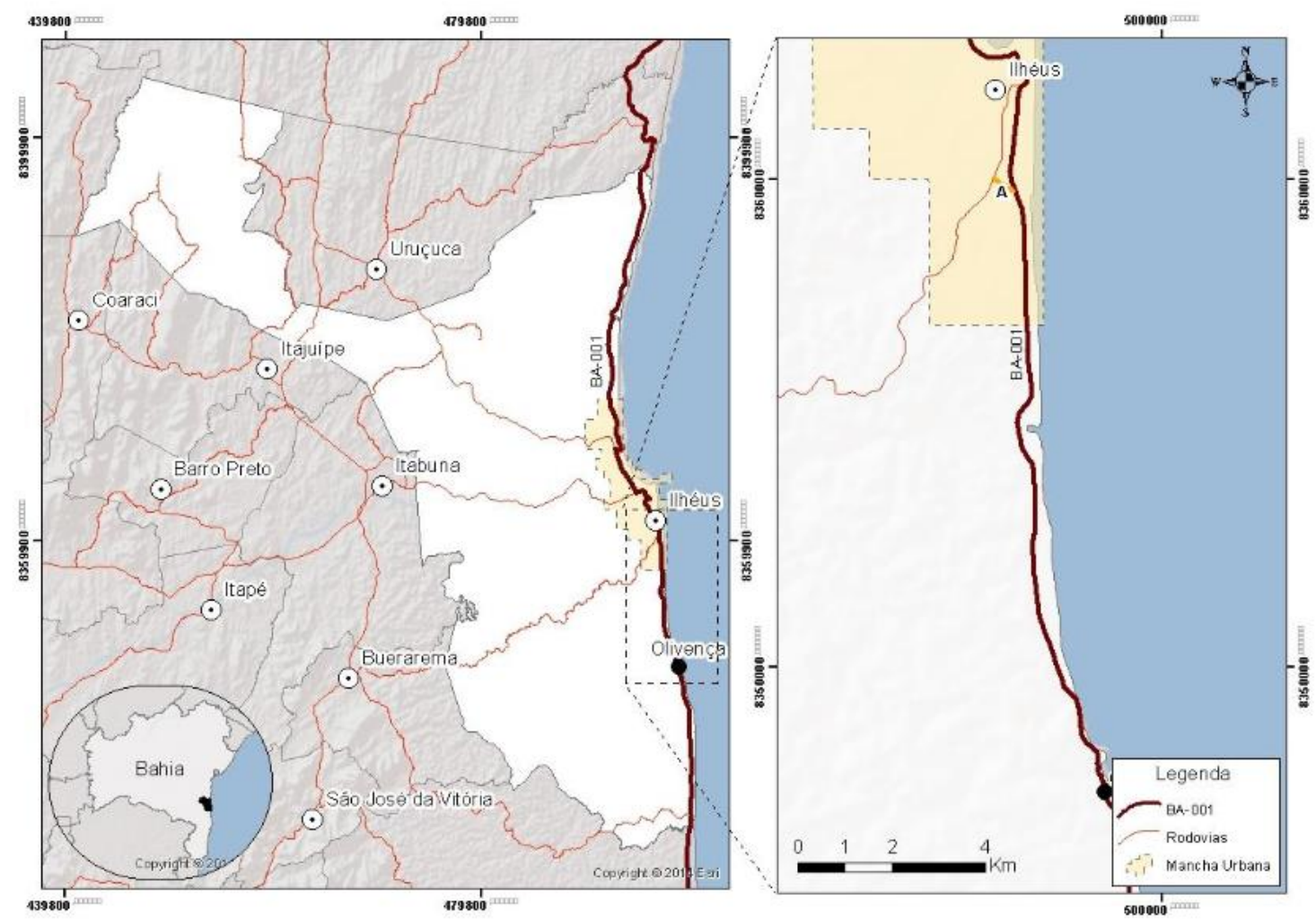

Figura 1. Mapa de localização da área de estudo: trecho da BA-001 que liga a cidade de Ilhéus ao distrito de Olivença. Fonte: SPANGHERO (2018)

Conforme podemos visualizar pela análise da figura 1, existe uma área localizada no trecho inicial da Rodovia Ilhéus-Olivença (BA-001) que está inserida dentro do perímetro urbano definido pelo

\footnotetext{
${ }^{3}$ A Rodovia BA-001 é uma rodovia litorânea construída em 1991 que liga os municípios baianos de Mucuri, localizado na microrregião de Porto Seguro à Vera Cruz, município localizado na borda leste da Ilha de Itaparica, microrregião de Salvador. De grande importância para a circulação entre os municípios baianos a rodovia foi originalmente concebida de forma a respeitar o bioma Mata Atlântica pelo qual atravessa, criando corredores ecológicos suspensos. Atualmente apresenta problemas infraestruturais ocasionados pela deterioração provocada pelos quase 30 anos de utilização da rodovia, parca manutenção e recuperações não-articuladas de trechos danificados da rodovia.

${ }^{4} \mathrm{O}$ dinamismo do mercado imobiliário na Zona Sul do município de Ilhéus é tamanho que recentemente foi inaugurada uma empresa - Imobiliária Atlântico Sul - especializada em negócios nessa área.
} 
município por meio da Lei n. 2296 de 15 de maio de 1989 e representada no mapa pelo polígono amarelo. Contudo identificamos a Avenida Oduvaldo Evaristo Bacelar (discriminada no mapa pela Letra A) como marco significativo para compreender a classificação da área de estudo pois, toda porção localizada ao sul dessa avenida, mesmo sendo localizada dentro do perímetro urbano não conta, por exemplo, com o serviço de entrega dos Correios.

Grosso modo, podemos afirmar que a população que reside ao sul da referida avenida e fora do polígono da mancha urbana transita entre o urbano e o rural pois, conforme procuraremos descrever a seguir, tem acesso - mesmo que precário - a alguns dos serviços urbanos que normalmente não são ofertados ao campo mas não tem acesso à equipamentos urbanos que em geral são instalados na zona rural por serem legalmente considerados como área urbana pelo município.

Como caracterização geral da área podemos afirmar que a coleta de lixo é irregular e ocorre em menor frequência que em bairros urbanos próximos; não há serviço de correspondência disponível, sendo que a população localizada ao sul da já mencionada Avenida Oduvaldo Evaristo Bacelar utiliza-se do serviço de posta-restante ou caixa postal, necessitando deslocar-se até o centro da cidade; identificamos grande dificuldade de transporte público - são poucas linhas de ônibus que atendem a população dessa área, os horários são irregulares e os pontos de ônibus são inseguros e precários; não há serviço de provedores de internet de banda larga via cabo disponíveis e o serviço de telefonia tanto fixa e quanto móvel - apresenta sérios problemas nas áreas localizadas fora do perímetro urbano; não foram identificadas escolas, nem postos de saúde, nem postos de vigilância, nem caixas eletrônicos em todo trajeto que liga o sul da avenida que estabelecemos como marco (A) até o distrito de Olivença, são raros os pontos de comércio não-turísticos e não existe iluminação pública além da área urbanizada que só alcança os três primeiros quilômetros do trecho estudado na Rodovia BA-001.

Apesar de todas as carências supracitadas, toda área de estudo é considerada oficialmente como área urbana pelo município, lembrando que para fins jurídicos a lei municipal pode considerar também como urbanas as áreas urbanizáveis ou de expansão urbana. 
A despeito da definição oficial, em termos práticos destacamos grande parte da área como rural devido à escassez de serviços públicos (alguns dos quais foram supracitados) e a ausência de equipamentos urbanos tais como escolas, postos de saúde, áreas públicas de lazer, área comercial, postos de vigilância, hospital, entre outros.

Assim como salientamos os elementos rurais na maior parte do trecho da rodovia em estudo, identificamos discrepâncias na classificação da área entre diferentes instâncias do poder público pois, enquanto o munícipio a qualifica como área urbana (considerada a área situada dentro do perímetro urbano e a área de expansão urbana), outras instâncias a classifica como área rural, como podemos perceber pela foto da figura 2, na qual registramos uma placa do Programa Luz para Todos, do Governo Federal, placa essa localizada no Km 7 da Rodovia, em uma área compreendida entre dois dos principais empreendimentos imobiliários investigados com maior nesse estudo.

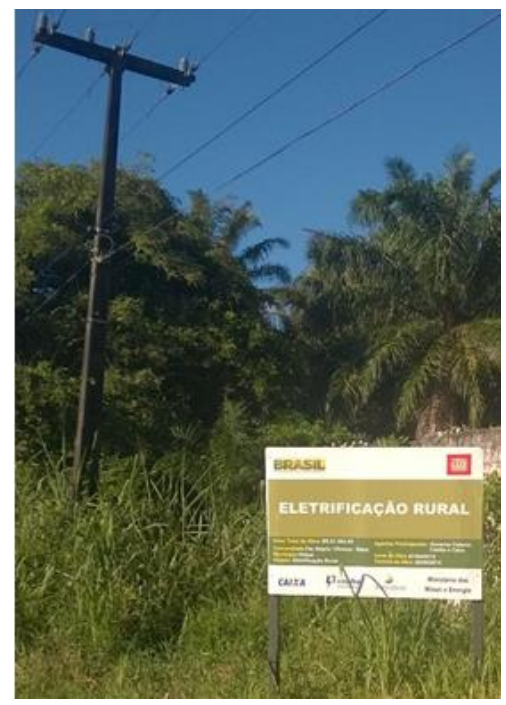

Figura 2. Fotografia de uma placa de Eletrificação Rural, nas imediações do Km 7 da Rodovia Ilhéus-Olivença (BA-001). Fonte: Pesquisa de campo (2016).

Parte dessa discrepância pode ser explicada pelo fato de que historicamente no Brasil a distinção entre áreas urbanas e áreas rurais tem sido determinada pelo critério formal, que considera os limites urbanos estabelecidos por lei. De acordo com a avaliação de Marques (2002, p. 97) a utilização desse critério apresenta problemas dentre os quais o fato de que "o urbano é definido pelo arbítrio dos poderes municipais, o que, muitas vezes, é influenciado por interesses fiscais”. 
Historicamente, essa área foi apontada pelo poder público como: a) área de interesse para expansão urbana no Plano Urbanístico Básico em 1979 (OLIVEIRA, 2008); b) área de expansão urbana na Lei 2.400/91 (ILHÉUS, 1991); e c) áreas prioritárias para desenvolvimento do turismo no município segundo o Plano de Estratégico de Turismo (ZENI, VISSIRINI \& LEAL, 2000).

Entretanto, nenhuma dessas ações foi capaz de promover o desenvolvimento efetivo da área de estudo, sendo provável que o afastamento geográfico e a precariedade dos serviços públicos tenham interferido nas decisões dos sujeitos do setor imobiliário em não investir nessa área.

Há pouco menos de 10 anos quem percorria as margens da Rodovia BA-001 percebia que a mesma era ocupada quase que exclusivamente por: a) mancha urbana que margeia o início da rodovia ( $\mathrm{km} 0)$ e se estende até aproximadamente o $\mathrm{Km} 3 ; \mathrm{b}$ ) infraestruturas turísticas: barracas de praia, algumas pousadas, restaurantes e hotéis; c) extensas áreas livres com vegetação nativa - vegetação litorânea e principalmente Mata Atlântica; d) propriedades rurais dispersas e pequenas aglomerações provenientes de antigos loteamentos e ocupação espontânea. Segundo Oliveira, na conclusão do Plano Urbano Básico de Ilhéus (PUB, 1979) as áreas praianas em direção à Olivença foram classificadas como "áreas planas desocupadas com densidades praticamente nulas" (OLIVEIRA, 2008, p. 85).

Em documento recente o IBGE reconhece que as tendências das classificações nas últimas décadas é evoluir de forma a abarcar as inúmeras mudanças na organização geográfica e a crescente complexidade do meio rural, mas ao mesmo tempo destaca que

\footnotetext{
Alguns fluxos relacionados à cacauicultura desapareceram e fluxos de outras naturezas emergiram em decorrência das atividades produtivas surgidas ou aprimoradas. Se as interações entre Itabuna-Ilhéus e as demais cidades da rede regional foram mantidas em um nível de interdependência que continua privilegiando os dois centros regionais em detrimento das pequenas cidades, isto significa que os laços engendrados pela cacauicultura foram tão bem atados que, mesmo após tantas transformações, continuam mantendo hierarquias difíceis de serem superadas (TRINDADE, 2015, p. 155).
}

Avaliamos que a atuação do mercado imobiliário na região só intensificou a partir de 2010, quando o enorme sucesso de vendas do empreendimento VOG - João de Góes sinalizou a real demanda por imóveis nas famosas Praias do Sul, não obstante os diversos níveis de precariedade que as cercam. 
Na próxima sessão investigaremos brevemente o contexto de desenvolvimento do turismo no município e as recentes transformações decorrentes da apropriação do espaço pelo mercado imobiliário nessa área de estudo.

\section{De point turístico à local de moradia: precariedade $\mathrm{X}$ marketing imobiliário}

Uma atividade de grande expressão econômica implantada no Sul da Bahia no contexto pós-crise da vassoura-de-bruxa foi o turismo, sendo que o município de Ilhéus, por ser litorâneo, foi beneficiado pelos investimentos turísticos realizados pelo Governo do Estado, sobretudo a partir da década de 1990. Silva B. et. al. (2004, p. 133) explicam o desenvolvimento da atividade em âmbito estadual salientando que.

\footnotetext{
Até a década de 1970 do século passado, o turismo só possuía expressão em Salvador e em seus arredores, onde tinha começado na década de 1950. Nas décadas de 80 e 90, sobretudo na última, cresce o turismo no litoral e na Chapada Diamantina.
}

Chiapetti (2009) explica que na década de 1990 as ações do governo estadual no que tange o desenvolvimento do turismo foram reforçadas a partir da integração da Bahia no PRODETUR/NE em 1995 e que, nesse contexto foram criadas as zonas turísticas, dentre as quais identificamos a Costa do Cacau que é composta por seis municípios do Sul da Bahia: Itacaré, Uruçuca, Ilhéus, Una, Santa Luzia e Canavieiras.

Além dos diversificados atrativos naturais e históricos, outro fator crucial para a compreensão do turismo no Sul da Bahia está ligado à ampla divulgação das obras do escritor Jorge Amado, uma vez que suas histórias, traduzidas e comercializadas em mais de cem países, são ambientadas no território do cacau, atraindo a atenção de muitos turistas.

Embora a atividade turística seja de grande relevância em âmbito local, segundo os dados da Secretaria do Turismo do Estado da Bahia (2012), a Costa do Cacau participa com apenas 3,8\% do fluxo turístico do Estado. Dentre os 6 municípios que compõe a zona turística, Ilhéus concentra as principais infraestruturas de circulação: o porto internacional e o aeroporto nacional, além da rodoviária que permite o deslocamento para os principais municípios baianos e municípios de outros estados. 
Especificamente no caso de Ilhéus, segundo dados do IBGE (2016), 48\% do PIB é proveniente do setor de serviços e nesse setor o grande destaque, de acordo com a SEI (2003) é a atividade turística. Dentre os principais destinos turísticos do município estão as Praias do Sul, localizadas em nossa área de estudo, sobretudo nos cinco primeiros quilômetros da rodovia, onde se concentram não apenas os principais estabelecimentos destinados ao veraneio como também os empreendimentos imobiliários investigados nesse artigo, com exceção de um loteamento, o Alphapark.

Como forma de melhor compreender a relevância da atuação do mercado imobiliário na recente apropriação do espaço na área de estudo revisitamos o histórico de ocupação desse trecho da rodovia e verificamos que diferentemente das ações que hoje se desenvolvem a ocupação histórica dessa área foi fundamentalmente orientada por ações do Estado.

O trabalho de Oliveira (2008) investiga a ocupação urbana entorno dos três quilômetros iniciais da Rodovia Ilhéus-Olivença (BA-001), área localizada dentro do perímetro urbano, em detalhe na figura 3.

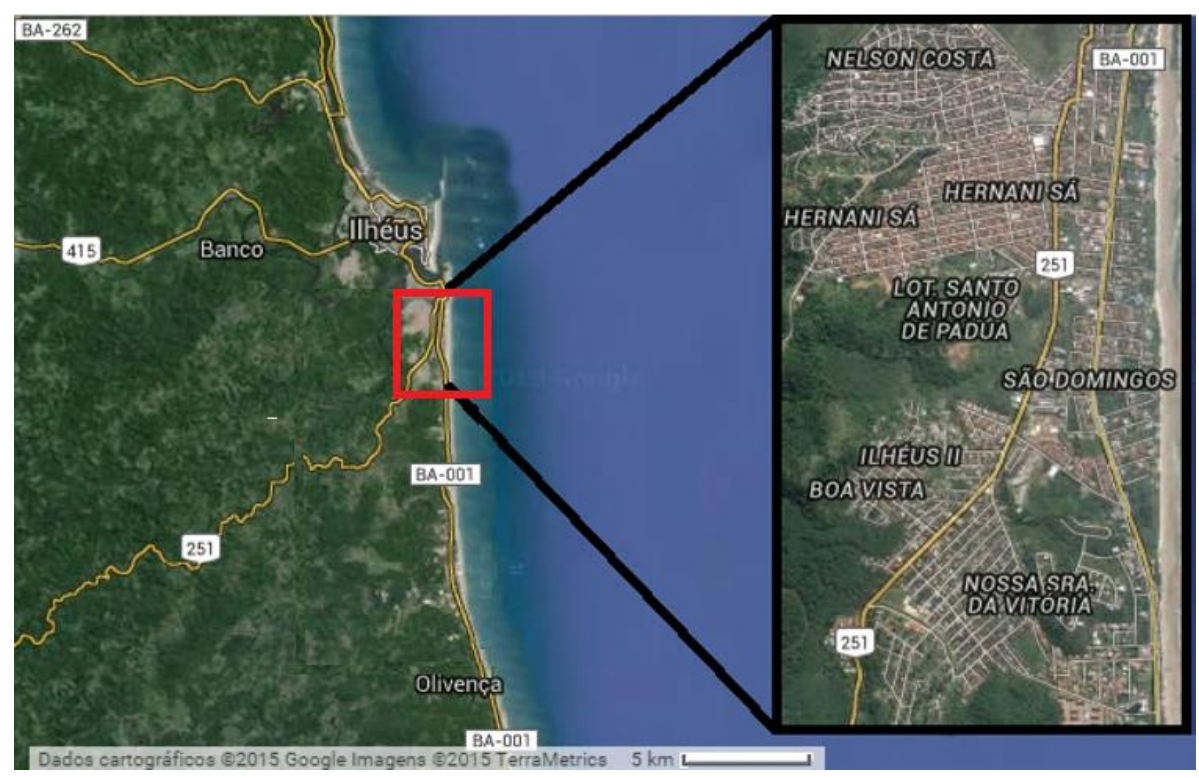

Figura 3. Imagem de satélite detalhando o trecho fortemente urbanizado nos quilômetros iniciais da Rodovia Ilhéus-Olivença (BA-001). Fonte: Oliveira (2008).

A partir do trabalho de Oliveira (2008) identificamos que a ocupação desse trecho inicial da rodovia poderia ser agrupada em três períodos principais: 1920-1940, 1960-1980 e 1980-2000, sendo que a cada um desses períodos corresponde um núcleo de urbanização. 
Entre 1920 e 1940 teria se desenvolvido o núcleo inicial de urbanização que teria se concentrado no primeiro quilômetro da rodovia no trecho Ilhéus-Olivença e seria o resultado de uma política de saneamento urbano (OLIVEIRA, 2008).

Um segundo núcleo urbano desenvolveu-se entre 1960 e 1980, atingindo até aproximadamente o Km 2 da rodovia e, embora esse núcleo tenha se desenvolvido a partir da ocupação espontânea, o autor avalia que esses fluxos foram resultado direto da construção da Ponte Ilhéus-Pontal $(1966)^{5}$ que permitiu a migração de grandes contingentes populacionais para a Zona Sul (OLIVEIRA, 2008).

Por fim, o terceiro núcleo de urbanização teria se desenvolvido entre os anos 1980 e 2000 atingindo até o Km 3 da rodovia. Para Oliveira (2008), esse último período de crescimento urbano teria sido resultado direto do aumento da demanda turística e da implementação de programas habitacionais:

No início da década de 80, com o asfaltamento da rodovia Ilhéus-Olivença (BA 001), foram implantados os loteamentos Gabriela e Jardim Atlântico. Esta rodovia consolidou-se como importante vetor turístico da cidade. Foram construídos loteamentos, clubes, bares, hotéis, restaurantes, suas praias eram as mais frequentadas na região (p. 90-91, grifos nossos).

Apesar do declarado interesse do poder público em promover a urbanização dessa e de outras áreas do município, quando da conclusão do Plano Urbanístico Básico em 1979 (In: OLIVEIRA, 2008), a autora expõe as dificuldades em concretizá-la:

inviabilidade econômica da infraestrutura, manutenção na "ilha" ${ }^{6}$ de grandes áreas vazias ou sub-ocupadas e a diluição e esvaziamento da capacidade de polarização da área central frente ao padrão de desenvolvimento disperso e extensivo no continente (OLIVEIRA, 2008, p. 107-108, grifo nosso).

Vinte e um anos depois, o Plano Estratégico de Turismo do município de Ilhéus (ZENI, VISSIRINI \& LEAL, 2000) reconhecia as deficiências infraestruturais ${ }^{7}$ e a carência de serviços públicos ${ }^{8}$ como

\footnotetext{
${ }^{5}$ Vale ressaltar que até hoje essa ponte é a única forma de comunicação entre o centro histórico e comercial do município de Ilhéus e a Zona Sul. Antes da construção da ponte, o transporte era realizado por pequenas embarcações via Baía do Pontal. Nesse sentido, Oliveira (2008) destaca que a construção da ponte possibilitou a ocupação espontânea da Zona Sul.

${ }^{6}$ Oliveira explica que "A cidade está situada sobre uma grande ilha formada por 10 morros: São Sebastião, Vitória, Boa Vista, Tapera, Conquista, Basílio, Esperança, Coqueiro, Amparo e Soledade, desde o início da sua ocupação, estes impuseram restrições e as possibilidades de expansão estavam limitadas para o sul pela baía do Pontal; ao norte pelos manguezais, pelo canal artificial de Itaípe e pelo Rio Almada; e a oeste pelo Rio Itacanoeiros" (OLIVEIRA, 2008, p. 60).

${ }^{7}$ No tópico deficiências infraestruturais os autores listaram: "Sinalização de tráfego e localização de equipamentos turísticos e rotas turísticas; Falta de iluminação adequada; Precariedade de saneamento básico com escoamento de detritos nas praias;
} 
"fraquezas internas" da nossa área de estudo. Os autores apontavam esses dois tópicos, juntamente com a precariedade no atendimento ao turista, como os principais obstáculos para o desenvolvimento das potencialidades turísticas dessa região.

Da análise desses documentos oficiais podemos inferir que ao longo das décadas que separam o Plano Urbanístico Básico de Ilhéus de 1979 (In: OLIVEIRA, 2008) e o Plano Estratégico de Turismo (ZENI, VISSIRINI \& LEAL, 2000) não foram implementadas ações efetivas para urbanização dessa área embora, como vimos em destaque em um dos excertos de Oliveira (2008), o asfaltamento do trecho entre Ilhéus e Olivença tenha permitido a apropriação desse espaço pelo turismo (até então ainda incipiente) e favorecido iniciativas isoladas de apropriação do espaço; iniciativas essas tão dispersas geograficamente que praticamente não conseguimos identificá-las na imagem de satélite da figura 3 .

A maioria das construções desse período é de loteamentos e condomínios de pequeno e médio porte ocupados como segunda residência nos períodos de veraneio. Esses empreendimentos antigos não apresentam grande infraestrutura sendo que mesmo nos casos de condomínios fechados não observamos asfaltamento das vias públicas nem áreas coletivas de lazer.

No entanto, conforme veremos a seguir, apesar da precariedade presente ainda hoje na área de estudo, esse trecho da rodovia se transformou em canteiro de obras, atraindo investidores e futuros moradores e concentrando os principais empreendimentos imobiliários de médio e alto padrão do município.

Esses novos empreendimentos que têm se desenvolvido a partir de 2010 diferem dos antigos em vários aspectos dentre os quais destacamos a forma de apropriação do espaço e o forte contraste com a realidade rural que os cerca. No que tange a apropriação do espaço pelo mercado imobiliário verificamos que a maioria das unidades familiares ligadas aos novos empreendimentos tem sido ocupada - seja pelo proprietário, seja por locatário - como residência principal e no que se refere à

Precariedade de calçamento no entorno dos equipamentos turísticos e Precariedade na manutenção e conservação da arquitetura histórica" (ZENI, VISSIRINI \& LEAL, 2000, p. 03).

${ }^{8}$ No tópico carências do serviço público os autores identificaram: "Precariedade no serviço de remoção de lixo; Precariedade no serviço de transporte urbano; Precariedade no serviço de telefonia; Precariedade no serviço de policiamento; Precariedade no serviço médico" (ZENI, VISSIRINI, LEAL, 2000, p. 04). 
realidade rural, discutida no primeiro segmento, vale destacar que a maioria dos empreendimentos imobiliários parecem reconhecer as limitações da área de estudo, uma vez que tendem a se concentrar próximos da área urbanizada, nos quilômetros iniciais da rodovia.

Até o presente momento, apenas os loteamentos conseguiram se desvincular da área fortemente urbanizada explorando, para tanto, outras estratégias como o alto padrão dos empreendimentos, as dimensões superiores dos terrenos e os atributos de localização. Para a apropriação desses espaços muito contribuiu, em nossa avaliação, o investimento no marketing imobiliário que passou a propagar slogans e discursos que ressaltam a proximidade com a natureza, a qualidade de vida e o status de viver nas praias mais cobiçadas do município.

O trabalho de Henrique (2005) discute essa prática que consiste na exploração da relação homem e natureza visando a valorização imobiliária:

Como parte do espaço geográfico, como elemento do território usado, a natureza é incorporada e produzida, como objeto e ideia, transformada em recurso pela valorização do espaço e por um intenso uso de território (HENRIQUE, 2005, p. 02).

Tal qual como descrito por Henrique (2005) no estudo de caso do município de Florianópolis, identificamos em Ilhéus, particularmente na Zona Sul "um processo de valorização monetária de loteamentos e condomínios destinados a população de alta renda, a qual está sendo seduzida pela propaganda da qualidade de vida e da natureza" HENRIQUE, 2005, p. 02).

Outra característica discutida pelo autor no estudo de caso de Florianópolis é igualmente identificada na Zona Sul de Ilhéus: a denominação dos imóveis tende a ressaltar características do sítio urbano associadas à natureza (HENRIQUE, 2005). No caso específico da Rodovia Ilhéus-Olivença são predominantes as referências ao litoral, tais como: Brisa do Mar, Ocean Residence, Caminho do Mar, Cidadelle Praia do Sul entre outros.

A despeito das inúmeras dificuldades o mercado imobiliário tem conseguido consolidar - praticamente sem a ajuda do poder público - o trecho da Rodovia Ilhéus-Olivença como um novo vetor de expansão urbana, como analisaremos na próxima seção. 


\section{Mercado imobiliário em cidades médias: o estudo de caso da recente ocupação da Rodovia Ilhéus-Olivença (BA-001)}

Tendo como referência o trabalho de Oliveira (2008) que definiu três períodos de ocupação da BA-001 no trecho Ilhéus-Olivença, propomos um quarto período, no qual identificamos a significativa atuação do mercado imobiliário, utilizando como marco temporal inferior o ano de 2010, ano de lançamento do empreendimento VOG - João de Góes. A partir desse empreendimento observamos inúmeros outros, em diversas fases de desenvolvimento, que indicam a atração de significativos contingentes populacionais a curto e médio prazo.

É importante destacar que o recente incremento populacional é sobretudo de famílias de classe média e média alta - público alvo do mercado imobiliário em nossa área de estudo - porém há que se reconhecer que o interesse nesse público não é fato que se manifesta apenas em escala local, estando atrelado a um contexto mais amplo. Pereira (2013) explica que historicamente a maior parte dos recursos destinados a políticas habitacionais no Brasil privilegiaram a população de alta renda, mas, na atualidade, a classe média tem sido o principal alvo do mercado imobiliário (PEREIRA, 2013).

Embora os investimentos imobiliários na área de estudo sejam destinados a várias faixas de renda inclusive as populares - concentramos nossa análise nos empreendimentos de médio e alto padrão, por reconhecer que, na atualidade, nenhuma outra área do município apresenta tantos investimentos desse tipo de empreendimento.

Para tanto, empreendemos uma análise geral acerca do desenvolvimento do mercado imobiliário em cidades médias - categoria na qual enquadramos o caso de Ilhéus - e uma análise específica da recente ocupação do trecho entre Ilhéus e Olivença, no qual destacamos 4 empreendimentos - um prédio de apartamentos e três loteamentos - que apresentam importantes características para compreender o dinamismo desse mercado na área de estudo.

Conforme salienta Pereira (2013), investigar o mercado imobiliário não é tarefa simples pois envolve aspectos macroeconômicos (inflação, políticas fiscais, de crédito, crescimento do PIB, distribuição da renda per capita, entre outros), aspectos estruturais do segmento (adaptações das empresas, fusões e 
incorporações de grupos estrangeiros, relações com o poder público) e diversos aspectos locais. O autor explica que

Investigar as especificidades do mercado imobiliário é uma tarefa que desenvolve um complexo sistema de interligações, e compreensão de lógicas que possam ser capazes de satisfazer e compreender a realidade dessa determinada área, afinal, é um dos mais importantes setores da economia brasileira e, também de diversos países [...] Entre outras coisas, envolve as empresas responsáveis por apresentarem e lançarem novos empreendimentos no mercado, bem como a relação com instituições financeiras para fornecimento e auxílio no consumo da população em face aos imóveis disponíveis para compra e venda (PEREIRA, 2013, p. 23).

O autor afirma que a partir dos anos 2000 algumas condições macroeconômicas brasileiras sobretudo no que tange condições de financiamento, estabilização da moeda e leis de moradia através de aluguéis - favoreceram o desenvolvimento desse segmento por tornar o mercado de imóveis mais atrativo e mais acessível para uma parte maior da população (PEREIRA, 2013, p. 36) .

Nesse contexto, o autor defende que o fortalecimento do setor imobiliário e a ampliação da atuação do Estado em políticas de financiamento habitacional associado a outras questões como, por exemplo, a qualidade de vida e o menor custo-benefício de cidades de médio porte favoreceram a descentralização das metrópoles e a consolidação de um novo mercado - as cidades médias (PEREIRA, 2013).

A partir dessa conjuntura as cidades médias brasileiras passaram a apresentar grande desenvolvimento do setor imobiliário, sendo que algumas delas (sobretudo nas proximidades de grandes centros) chegaram a ultrapassar o ritmo de crescimento das metrópoles (PEREIRA, 2013). Na tentativa de compreender as especificidades de crescimento do mercado imobiliário em cidades médias, o autor analisa

Observa-se que apesar das diferenças das características de cada cidade média que passa pelo aquecimento do mercado de imóveis, três fatores básicos ficam evidenciados e que logicamente são capazes de "puxar" esse crescimento ou funcionamento da estrutura dinâmica imobiliária, os quais são: o setor industrial; o mercado (bens e serviços); e as políticas públicas. Essas três forças basicamente estão explícitas nos modelos estruturais da capacidade de desenvolvimento do setor de imóveis, ocasionando o crescimento urbano em uma região. Economicamente, as três forças em forma de pirâmide são complementares [...] (PEREIRA, 2013, p. 31).

9 Para fundamentar essa discussão Pereira (2013) faz referência à BRIDI, C. Setor Imobiliário Encontra Portas Abertas na Macroeconomia Brasileira. Matéria de Capa. Revista IBEF NEWS. Novembro, 2007. 
A comparação de alguns dados do IBGE (2002 e 2015) referente ao município de Ilhéus nos fornece alguns elementos para interpretar a tríade apresentada por Pereira (2013) a partir da realidade de nossa área de estudo e compreender a atual dinâmica do mercado imobiliário local.

A primeira importante observação refere-se ao expressivo aumento do PIB municipal. Em pouco mais de uma década verificamos um aumento de quase de $120 \%$, sendo que o valor adicionado bruto total do PIB ilheense passou de $R \$ 1.237 .277,00$ em 2001 para $R \$ 2.696 .274,00$ em 2013 (IBGE 2002; 2015).

Ao longo dessa década, a composição setorial do PIB do município também sofreu significativas transformações, conforme podemos verificar pela comparação da tabela abaixo.

\begin{tabular}{cccc}
\hline & $\mathbf{2 0 0 2}$ & \multicolumn{2}{c}{$\mathbf{2 0 1 3}$} \\
\hline Agropecuária & 49.191 & Agropecuária & 102.525 \\
Indústria & 702.610 & Indústria & 830.835 \\
Serviços & 485.426 & Serviços & 1.762 .914 \\
VALOR TOTAL & $\mathbf{1 . 2 3 7 . 2 2 \%}$ & VALOR TOTAL & $\mathbf{2 . 6 9 6 . 2 3 4}$ \\
\hline
\end{tabular}

Tabela 1. Composição setorial do PIB do município de Ilhéus 2002 e 2013 (em R\$). Fonte: IBGE (2002; 2015).

Conforme podemos observar pela análise da tabela 1 o setor agropecuário, de forte tradição local teve um crescimento de cerca de 50\% no período, enquanto o setor industrial manteve seu crescimento abaixo dos $20 \%$ na comparação entre os dois períodos. 0 grande destaque foi o setor de serviços, cuja participação aumentou cerca de 360\% entre 2002 e 2013. Esse setor que contribuía com cerca de 39\% na composição do PIB municipal em 2002 aumentou sua participação para aproximadamente 65\% nos dados de 2013.

Esses dados são significativos para a compreensão da atuação do mercado imobiliário pois de acordo com o relato de alguns agentes imobiliários consultados entre 2010 e 2012 , um dos maiores entraves para o pleno desenvolvimento da construção no município de Ilhéus era a prestação de serviços.

O relacionamento comercial (e em muitos casos trabalhista) com o município vizinho, Itabuna, era praticamente obrigatório em grandes obras, uma vez que Ilhéus não dispunha de grandes centros de distribuição de materiais de construção a preços competitivos, nem de abundância de profissionais especializados. 
O maior desenvolvimento do setor de serviços a partir dos anos 2000 parece ter sido crucial para 0 crescimento do setor imobiliário. A melhoria na prestação de serviços parece ter influenciado o fortalecimento da indústria da construção civil, favorecendo o boom dos empreendimentos imobiliários em escala local.

Também identificamos como fatores importantes para compreender o crescimento do setor imobiliário em Ilhéus: a inauguração de grandes lojas de materiais de construção (muitas subsidiárias de empresas de Itabuna); a realização de cursos técnicos públicos e privados voltados para capacitação de profissionais ligados à construção civil e o aumento do número de empresas cadastradas no município ${ }^{10}$.

Apesar do desenvolvimento econômico municipal, a análise da evolução da população indica uma emigração da ordem de $17 \%$ considerando os dados de 2001 - população de 221.661 habitantes - e 2013 - 184.236 habitantes (IBGE 2002; 2015). Se considerarmos a população estimada pelo IBGE para o ano de 2015 - 180.213 habitantes, a perda populacional em relação ao início dos anos 2000 gira em torno dos 20\% (IBGE, 2015), enquanto o crescimento populacional da cidade vizinha, Itabuna, permanece estável.

O incremento do PIB municipal e o déficit populacional impactaram significativamente o PIB per capita que quase triplicou no período, passando do valor de $R \$ 6.171,00$ em 2001 para $R \$ 17.369,00$ em 2013 (IBGE 2002; 2015).

Não obstante o aumento no valor do PIB e PIB per capita há que se ressaltar a profunda desigualdade na distribuição de renda municipal, uma vez que o salário médio mensal em 2010 era de 1,3 salários mínimos (IBGE, 2015).

Tendo analisado brevemente a relação entre indústria e prestação de serviços no município, resta-nos abordar o último condicionante apontado por Pereira (2013) para o crescimento do mercado imobiliário. Conforme nos expôs Pereira (2013) a partir dos anos 2000 o Governo Federal ampliou

\footnotetext{
${ }^{10} \mathrm{O}$ número de empresas privadas no âmbito municipal saltou de 3.569 em 2001 (IBGE, 2002) para 4.022 (sendo 4.239
} unidades) em 2013 (IBGE, 2015). 
sistematicamente a concessão de créditos habitacionais, orientando o mercado imobiliário para atender as necessidades da classe média brasileira.

No caso específico do município de Ilhéus, percebemos que o crescimento do mercado imobiliário poderia ser ainda mais expressivo se incluísse a também a população de baixa renda. Os estudos de Ramos e Noia (2014) indicam forte déficit habitacional no município, sobretudo entre essa camada da população e concluem que mesmo após a aplicação de recursos de programas federais como Minha Casa Minha Vida e PAC 2

As transformações urbanas empreendidas, desde a mais grave crise na economia cacaueira em 1989, gerou migração das áreas rurais e de cidades circunvizinhas para a zona urbana, em busca de melhores condições de vida, em função de a reorganização econômica ter sido, predominantemente, sustentada no setor de serviços e indústrias instaladas nos municípios, responsáveis pela geração de emprego e renda. Contudo, essa migração foi sendo realizada de maneira precária e segregada, sem contar com os problemas habitacionais já existentes antes mesmo da crise.

Quando essa realidade foi confrontada com os níveis de renda no ano de 2000, observou-se que o problema está concentrado na população de menor faixa de renda, grupo que pela exclusão social e econômica depende de política habitacional que subsidie o acesso a imóveis e intervenha nas regras de mercado. No entanto, quando se trata de Ilhéus e Itabuna, ainda existem limitações institucionais consideráveis que precisam ser superadas para dar maior consistência às intervenções que são realizadas (RAMOS \& NOIA, 2014, p 18).

Apesar da significativa atuação dos programas federais de habitação voltados para a população de baixa renda ainda é significativo déficit habitacional no município, tendo sido calculada em aproximadamente 6.500 domicílios por Ramos e Noia (2014). E, apesar das oportunidades de negócios geradas por esses programas habitacionais para o segmento imobiliário, os principais empreendimentos imobiliários em desenvolvimento no município destinam-se, por seus elevados preços de aquisição e condições de financiamento, à população de classe média e classe média alta.

Em geral, verificamos que os empreendimentos imobiliários em franca expansão exploram em suas campanhas publicitárias os atributos da localização até como forma de superar as limitações da área de estudo conforme descrevemos anteriormente. Seja por meio dos slogans das campanhas publicitárias seja na denominação dos empreendimentos, a proximidade com o mar e a existência de áreas verdes nativas são utilizadas pelas empresas para evocar a ideia de "melhor qualidade de vida", criando o desejo de habitar a área e inflacionando os preços. 
Ao que parece essa estratégia têm surtido resultados: o sucesso de vendas dos principais empreendimentos - sobretudo na fase de lançamento - parecem atrair de um lado investidores locais e extra-locais interessados na valorização imobiliária e, de outro, um significativo contingente de moradores (proprietários ou locatários) ${ }^{11}$.

Na figura abaixo apresentamos um panorama da área de estudo com a identificação dos principais empreendimentos imobiliários em diversas fases de desenvolvimento.

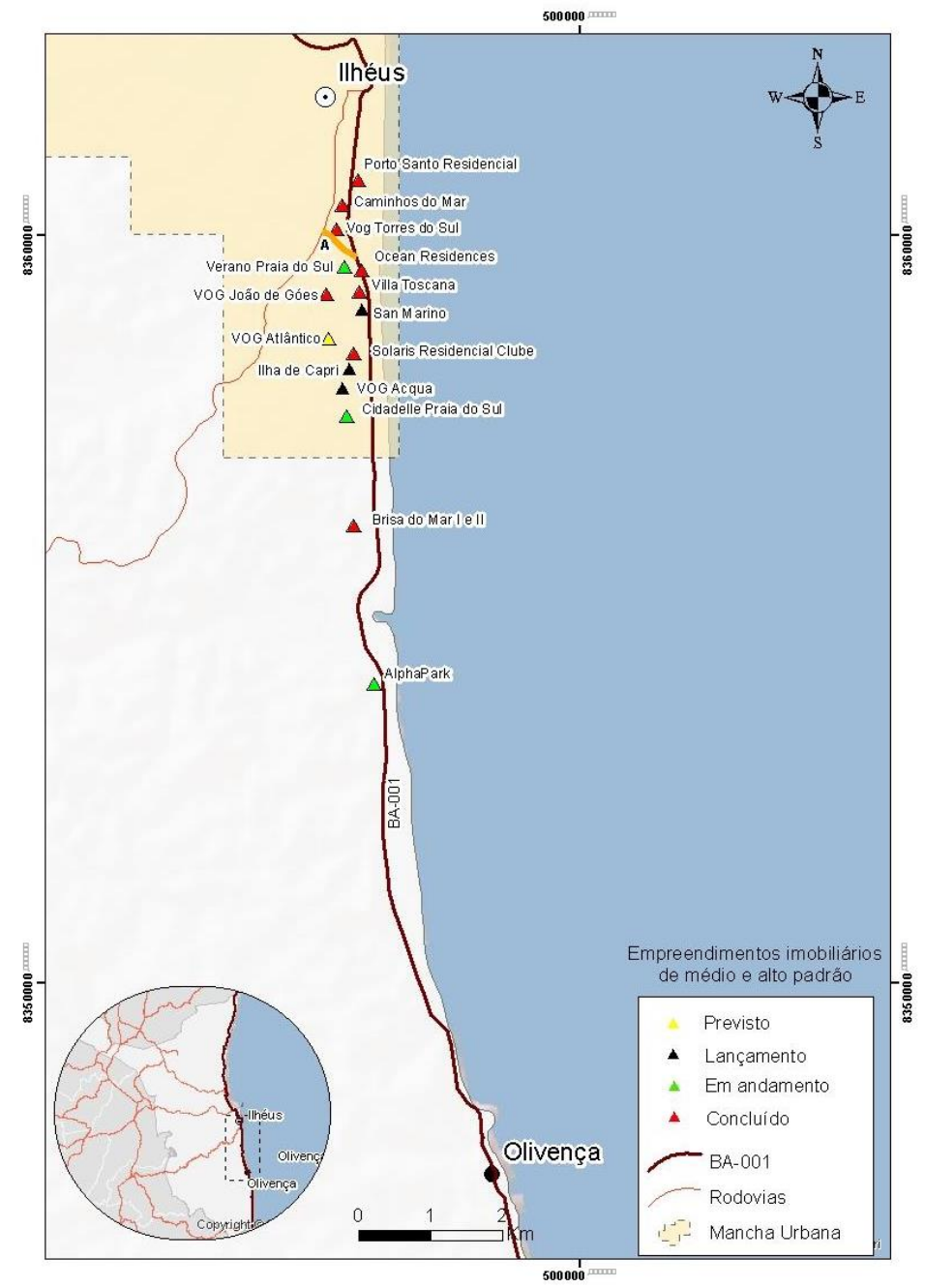

Figura 4. Rodovia Ilhéus-Olivença (BA-001): localização dos principais empreendimentos imobiliários de médio e alto padrão pós-2010. Fonte: Pesquisa de campo (2018). Elaboração: SPANGHERO (2018).

\footnotetext{
${ }^{11}$ Não temos dados suficientes para distinguir, com precisão, os imóveis de moradores e os destinados à segunda residência. No entanto, a partir da realidade do VOG João de Góes, empreendimento já concluído, avaliamos um crescente contingente populacional de residentes, confirmando o fluxo de ocupação urbana do tipo espontânea na região. Para fins ilustrativos citamos levantamento da empresa Fibra Técnica que identifica que "O Condomínio Habitacional VoG João de Góes [...] constitui-se por 480 unidades habitacionais, destinado a moradia de 1.920 habitantes de classificação socioeconômica média, além de uma população flutuante de 384 pessoas". Disponível em:

http://www.fibrasaneamento.com.br/site/index.php/blog/item/32-not\%C3\%ADcia-2-complexo-de-suape. Acesso em: $29 / 12 / 2015$
} 
Podemos observar pela análise da figura 4 que o perímetro urbano concentra a maior parte dos empreendimentos na área de estudo, embora, como vimos, isso não garante necessariamente acesso aos serviços e equipamentos urbanos.

Também podemos identificar que todos os empreendimentos imobiliários que serão detalhados nesse estudo - Solaris Residencial Clube, VOG João de Góes, Cidadelle Praia do Sul, Brisa do Mar I e II e Alphapark localizam-se ao sul da Avenida Oduvaldo Evaristo Bacelar estando sujeitos as condições já expostas acerca dessa área.

Em geral, os novos e os futuros moradores dessa área são de um extrato da população com maior poder aquisitivo disposto a enfrentar alguns dos problemas decorrentes do afastamento urbano em nome da dita "melhor qualidade de vida". A posse de veículo é vista praticamente como uma necessidade entre os novos moradores diante da precariedade dos serviços públicos de transporte nessa região.

E não nos parece mera coincidência o fato de que a partir dos anos de 2013 e 2014, a Zona Sul de Ilhéus passar a enfrentar imensos congestionamentos diários, até então típicos dos períodos de veraneio. Os primeiros empreendimentos imobiliários lançados em meados de 2010 foram entregues justamente a partir dessa data, intensificando o povoamento da Zona Sul. Até hoje, diariamente, nos horários de pico o tráfego sob a Ponte Lomanto Júnior apresenta longos congestionamentos - no período da manhã no sentido Zona Sul-Ilhéus e no período da tarde no sentido inverso, o que parece confirmar o aumento significativo de moradores na Zona Sul e o crescente número de veículos particulares $^{12}$ nessa área do município ${ }^{13}$.

\footnotetext{
${ }^{12}$ A frota municipal cresceu significativamente entre os anos de 2005 e 2014, sobretudo se relacionarmos esse crescimento à forte emigração observada no período. A análise dos dados do IBGE (2015) revelam crescimento concentrado entre veículos particulares - carros e motos. Os automóveis eram 8.364 em 2005 e agora são 17.730 (aumento de mais de 110\%); as motos aumentaram de 2.103 em 2005 para 8.806 (crescimento de quase 320\%); enquanto os ônibus e micro-ônibus, em geral utilizados para transporte público, que totalizavam 321 em 2005 aumentaram para 471 em 2014 (acréscimo de cerca de $46 \%$ ).

${ }^{13}$ Em 2016, impulsionada pela pressão popular, iniciou-se a construção de uma nova ponte que irá ligar o bairro do Pontal (e toda Zona Sul) ao centro da cidade de Ilhéus. As obras já estão em andamento e a previsão de entrega é em 2018.
} 
Mira (2015) avalia que a valorização imobiliária relacionada ao turismo na Costa do Cacau "reflete a associação de dois fatores siameses: o incremento da demanda turística e as melhorias infraestruturais em grande parte resultantes de pressão da atividade turística" (p. 147).

Como fontes do incremento da demanda turística podemos citar: a melhoria de algumas das rodovias estaduais e intermunicipais da rede sul-baiana; a existência de um porto internacional; políticas públicas e iniciativas privadas e público-privadas de fomento ao turismo local e à preservação do patrimônio histórico (CHIAPETTI, 2009), além do aumento real da renda em cenário nacional, permitindo assim a ampliação da prática do turismo.

No entanto, no que tange as melhorias infraestruturais citadas por Mira (2015), como o segundo fator relacionado à valorização imobiliária avaliamos que, especificamente no caso da nossa área de estudo, essas melhorias estariam circunscritas aos novos empreendimentos imobiliários. Praticamente inexistem ações públicas de infraestrutura ao longo da rodovia, excetuando-se a área urbanizada (nos três primeiros quilômetros) e o núcleo distrital.

Entretanto, os novos empreendimentos imobiliários passaram a investir amplamente em infraestrutura e segurança, diferentemente dos empreendimentos mais antigos encontrados na região. Esses investimentos, por sua vez, têm retroalimentado a valorização imobiliária da área, atraindo cada vez mais investidores e população de maior poder aquisitivo, disposta a conviver, ou melhor, contornar com recursos próprios e com a estrutura fornecida pelos referidos empreendimentos, a precariedade dos serviços públicos e a ausência de equipamentos urbanos. É nesse sentido que utilizamos a expressão enclaves de urbanidade para identificar esses novos empreendimentos de médio e alto padrão construídos num universo praticamente rural.

O conceito de enclave em Geopolítica e nas ciências sociais geralmente remete a um território - oficial ou não - que se localiza completamente dentro de outro, distinguindo-se substancialmente do território que o rodeia. Caldeira (1997) que discute em um de seus trabalhos a proliferação de enclaves fortificados em cidades ao redor do mundo os define como "espaços privatizados, fechados e 
monitorados para residência, consumo, lazer ou trabalho" (CALDEIRA, 1997, p. 155). A autora ainda explica, no contexto de seu trabalho que

A imagem dos enclaves opõe-se à da cidade, representada como um mundo deteriorado, permeado não apenas por poluição e barulho, mas principalmente por confusão e mistura, ou seja, heterogeneidade social e encontros indesejáveis (p.160).

Inspirada na definição da autora, esse trabalho propõe a expressão enclaves de urbanidade para explicar a recente ocupação da área de estudo. Apesar do fato de que praticamente todos esses empreendimentos são do tipo fechado - e nesse sentido poderiam ser classificados pela definição da autora - a característica que os ressalta em escala local é que promovem a urbanidade em uma área que é essencialmente rural.

No âmbito do estudo do tema da relação cidade-campo, os termos urbanidade e ruralidade são geralmente associados à caracterização das condições (materiais e imateriais) da reprodução social das populações rurais e urbanas independentemente do espaço físico que habitam (NEVES, 2010). Como explica Rosas (2009)

\footnotetext{
Embora cada espaço possua seus valores, hábitos, práticas e comportamentos específicos, estes são produzidos e reproduzidos por pessoas, de maneira harmoniosa ou na maioria das vezes, conflituosa, podendo ser representadas em espaços diversos, como um homem ou o conjunto desses em uma cidade, ou pessoas habituadas à vida da cidade, com suas prerrogativas urbanas, vivendo no espaço rural. A expressão e materialização desse conjunto de relações do rural e do urbano, cada qual em seu determinado espaço, são consideradas ruralidades e urbanidades, porém, essa lógica acaba transcendendo os "limites" do campo e da cidade, podendo ocorrer urbanidades no campo e ruralidades na cidade (p. 10, grifo nosso).
}

Assim, diante do estudo de caso em investigação, a expressão enclaves de urbanidade é utilizada para reforçar a segregação socioespacial característica da apropriação do espaço pelo mercado imobiliário a partir dos anos 2010. Sendo a maioria dos novos empreendimentos do tipo fechada e dotada de infraestruturas próprias a segregação a que nos referimos atinge não só a livre circulação de pessoas como também o acesso à serviços e equipamentos urbanos que passam a estar disponível - em maior ou menor grau - para a população residente nesses empreendimentos, fato que permite a seus moradores o desenvolvimento do modo de vida urbano, mesmo num universo que poderia ser melhor classificado como rural. 
Dentre os novos empreendimentos imobiliários em diversas fases de desenvolvimento ao longo da Rodovia Ilhéus-Olivença (BA-001), identificamos três tipos principais: edifícios, conjuntos habitacionais e loteamentos.

O edifício consiste em uma única unidade vertical subdividida em apartamentos. Os edifícios podem apresentar números variáveis de andares e unidades individuais. Até então, na área de estudo, os inúmeros prédios, em suas distintas fases de edificação são quase exclusivamente residenciais. Embora a área de estudo apresente inúmeras edificações, a maioria apresenta baixo porte, com média de 5 andares que dispensa a obrigatoriedade da instalação de elevadores.

A exceção é o Solaris Residencial Clube, inaugurado no final do ano de 2015, que é um dos empreendimentos que destacamos nesse estudo. O edifício é o primeiro de grande porte da área de estudo apresentando 19 pavimentos, 132 apartamentos e ampla infraestrutura de lazer e, segundo a construtora, é o maior edifício residencial da cidade de Ilhéus (CICON, 2015), fato que pode ser utilizado para exemplificar o intenso dinamismo do setor imobiliário que vimos afirmando.

A segunda categoria identificada entre os novos empreendimentos na área de estudo é a de conjunto habitacional (de livre acesso ou fechados) que consiste no conjunto de vários prédios de apartamentos que, juntos, compõe um empreendimento único. Esses complexos são fruto de uma mesma gleba e podem ou não apresentar áreas de lazer coletivas.

Nos conjuntos habitacionais identificados na área de estudo essas áreas de lazer são cada vez mais sofisticadas - compostas por brinquedotecas, piscinas, deck molhado, salão de festas, salão de jogos, espaço gourmet, academia de ginástica, parque infantil, área de churrasqueira, quadras esportivas, entre outras - pois esses elementos de lazer, juntamente com os atributos de localização (geralmente associados à vista para o mar ou distância em minutos da praia) são "chamarizes" do mercado imobiliário. Interessante notar que muitas vezes os anúncios das áreas de lazer nos materiais publicitários parecem indicar uma competição entre os diversos empreendimentos.

Na análise da categoria conjunto habitacional, destacamos o empreendimento VOG João de Góes, lançado em 2010 em parceria com a Caixa Econômica Federal. O empreendimento é um condomínio 
fechado composto de 15 edifícios e 480 apartamentos tendo sido o primeiro empreendimento de médio padrão na orla sul a oferecer uma série de itens de lazer (que são poucos em comparação com os que são previstos para obras em andamento na área de estudo).

Apesar das limitações que caracterizam a área de estudo no que tange serviços e equipamentos urbanos o empreendimento conseguiu atrair grande contingente populacional para moradia regular, contrariando a tendência dos condomínios mais antigos de predomínio imóveis de segunda residência.

Quanto ao tamanho das unidades residenciais dos novos empreendimentos da Zona Sul de Ilhéus identificamos que tanto os edifícios quanto os conjuntos habitacionais apresentam apartamentos que variam entre $48 \mathrm{~m} 2$ e $80 \mathrm{~m} 2^{14}$ - cujos valores de mercado ainda na planta indicam que o público alvo é a classe média e à classe média alta.

Por fim, os loteamentos são o terceiro e mais recente tipo de novos empreendimentos imobiliários nesse trecho da Rodovia Ilhéus-Olivença. São empreendimentos fundamentalmente horizontais, de alto padrão, gabarito variável de acordo com a empresa responsável, podendo ser do tipo aberto ou condomínio fechado. Vale ressaltar que esses novos loteamentos apresentam terrenos de dimensões muito superiores aos encontrados na zona urbana $^{15}$ : enquanto os terrenos da área central do município e adjacências variam entre $200 \mathrm{~m} 2$ e $400 \mathrm{~m} 2^{16}$ os novos loteamentos tem suas proporções mínimas estabelecidas em $450 \mathrm{~m} 2{ }^{17}$.

Por configurarem uma nova forma de apropriação do espaço pelo mercado imobiliário não somente na área de estudo como na região como um todo, optamos por detalhar melhor esses empreendimentos.

0 "Brisa do Mar" localizado no Km 05 da Rodovia Ilhéus-Olivença (BA-001) é o único desses loteamentos de grande porte e de alto padrão que já foi concluído. Ele teve sua $1^{\mathfrak{a}}$ etapa de vendas

\footnotetext{
${ }^{14}$ Fonte: Materiais publicitários diversos.

${ }^{15}$ Lembrando que Ilhéus é um sítio urbano muito antigo, fundado em 1534, e que a malha urbana do município foi construída seguindo outras necessidades.

${ }^{16}$ Encontramos no espaço urbano ilheense medidas muito irregulares de terrenos. Dependendo da localização os terrenos populares da Zona Sul variam suas medidas, por exemplo, entre 5 x $40 \mathrm{~m}^{2}$ - um terreno médio no Bairro Pontal - até 15 x $20 \mathrm{~m}^{2}$ - um terreno no bairro Nossa Senhora da Vitória. Em áreas mais nobres da Zona Sul, os terrenos apresentam terrenos maiores, por volta de $12 \times 25 \mathrm{~m}^{2}$ e dimensões superiores.

${ }^{17}$ Fonte: Materiais publicitários e anúncios imobiliários.
} 
lançada em 2013 (141 lotes) e a $2^{\text {a }}$ etapa em 2014 (149 lotes) e foi entregue pavimentado, com redes próprias de esgoto, água e elétrica, iluminação pública e drenagem de águas pluviais ${ }^{18}$. Diferentemente dos outros dois loteamentos que destacamos nesse estudo, o Brisa do Mar I e II foi idealizado para ser uma um loteamento do tipo aberto, embora pudesse ser convertido em condomínio fechado por decisão da Assembleia de Moradores.

Apesar dos 141 lotes da primeira etapa do empreendimento terem sido todos vendidos no dia de seu lançamento $^{19}$, fato incomum no mercado imobiliário local, o empreendimento não foi ainda povoado pois quase dois anos se passaram desde sua entrega e observamos apenas meia dúzia de casas construídas/em construção.

Os outros dois loteamentos de alto padrão da Rodovia BA-001 ainda estão em andamento e foram planejados como condomínios fechados com ampla infraestrutura de lazer. São os empreendimentos "Alphapark" (Km 7) e "Cidadelle Praia do Sul" (Km 5), ambos lançados no ano de 2014 respectivamente nos meses de fevereiro e junho. Esses empreendimentos imobiliários encontram-se ainda em sua primeira etapa de vendas, sendo 261 lotes no Alphapark e 440 lotes no Cidadelle Praia do Sul, embora ambos prevejam uma segunda etapa.

Para a segunda etapa do Alphapark ${ }^{20}$ estão previstos mais 343 lotes e cinco grandes áreas para implantação comercial enquanto que a segunda etapa do Cidadelle Praia do Sul ${ }^{21}$, prevê a construção de um Shopping Center com capacidade para 145 lojas.

Os três loteamentos de alto padrão identificados na área de estudo evocam a ideia da aproximação com a natureza e destacam a qualidade de vida que essa aproximação proporciona aos moradores de seus empreendimentos. Nos materiais publicitários desses empreendimentos, identificamos frases e slogans

\footnotetext{
${ }^{18}$ Disponível em:

http://www.urbplansa.com.br/site.aspx/Detalhe-Busca-Empreendimento?Est=29\&Cid=363. Acesso em: 22/12/15.

${ }^{19}$ No lançamento da primeira etapa do empreendimento Brisa do Mar - primeiro loteamento da área de estudo - todos os 141 lotes foram vendidos em menos de 3 horas. Disponível em: http://www.pimenta.blog.br/2013/01/21/o-case-brisa-domar/\#more-119440. Acesso em: 06/01/2016.

${ }^{20}$ Disponível em: http://www.alphaparkilheus.com.br/. Acesso em: 21/01/2016.

${ }^{21}$ Disponível em: http://www.cidadelle.com.br/praia-do-sul-house.html. Acesso em: 22/12/15.
} 
tais como: "extensa área verde", "Venha ser feliz entre o mar e a natureza preservada da Mata Atlântica" e "Aqui as férias duram o ano inteiro".

Interessante notar que o mesmo "verde" explorado pelo marketing imobiliário na pré-venda e lançamento dos empreendimentos é, em grande parte, reduzido entre as primeiras ações da fase de implantação dos loteamentos. Mais tarde, os remanescentes de vegetação nativa novamente são apropriados para promover o lançamento da segunda etapa de vendas, que ao ser implantada resulta em novas ações de desmatamento sendo que, na prática, após o empreendimento finalizado poucas áreas verdes estarão preservadas. Como exemplo, citamos o material de divulgação de um dos empreendimentos que anuncia uma área verde de mais de $25.000 \mathrm{~m}^{2}$ preservada na primeira etapa e, no mesmo material, nos oferece um panorama geral do empreendimento, com a apresentação da área a ser ocupada pela segunda etapa. A análise desse material nos aponta que o "verde" que supostamente promoveria uma melhor qualidade de vida aos futuros moradores não apresentará as dimensões anunciadas após a finalização do empreendimento e ainda estará confinado em áreas impróprias para a comercialização sob a forma de lotes devido à acentuada declividade do terreno.

Ao contrário desse empreendimento, em particular, que nos fornece elementos para perceber essa dupla apropriação da natureza, fazendo a distinção entre a área verde original, a área preservada na primeira etapa e a área verde que vai permanecer de fato, uma vez concluído o empreendimento, essas questões nem sempre estão claras para os potenciais compradores e futuros moradores.

Outra questão importante a se reconhecer é que a intensificação da apropriação do espaço às margens da Rodovia Ilhéus-Olivença será acompanhada por fluxos de ocupação espontânea nos próximos anos. Esses fluxos estão, em primeiro plano, diretamente associados à inauguração dos novos empreendimentos imobiliários, embora não se restrinja a eles. A reboque dos fluxos criados por essa forte atuação do mercado imobiliário na área de estudo identificamos também a intensificação da ocupação de áreas populares - tanto áreas novas (que não foram analisadas nesse trabalho) quanto antigas. Esses fluxos parecem ser de famílias de trabalhadores que buscam prestar serviços aos novos moradores de classe média e média alta, residentes nos empreendimentos. 
Embora segregada das inovações implantadas na área de estudo a população em geral também está sujeita aos impactos dessa recente ocupação, sobretudo no que tange o inflacionamento dos preços dos imóveis na área de estudo, mesmo em áreas de ocupação mais antigas.

De acordo com os dados fornecidos pelos sujeitos entrevistados (moradores, trabalhadores, corretores de imóveis e agentes imobiliários) e os dados registrados pelo acompanhamento da evolução dos preços na área de estudo constatamos que, até meados de 2010, era possível encontrar terrenos populares na faixa de 5 a 6 mil reais nas áreas distantes no núcleo urbano e distrital (pequenas aglomerações semelhantes a pequenos bairros) e terrenos dentro dos condomínios e/ou em loteamentos mais antigos a partir de 35 mil reais. Atualmente os terrenos à venda nas mesmas áreas variam entre 15 e 20 mil reais em áreas populares, enquanto que nos condomínios e loteamentos antigos, os valores médios de terrenos estão em torno de 80 a 100 mil reais $^{22}$.

Nos loteamentos recentes os preços de terrenos são ainda mais valorizados: os três empreendimentos detalhados nesse estudo têm dimensões mínimas estabelecidas em $450 \mathrm{~m}^{2}$. Na fase de lançamento o preço de um terreno desse tamanho no Brisa do Mar I era de cerca de 90 mil reais enquanto nos empreendimentos Alphapark e Cidadelle Praia do Sul os terrenos variavam entre 120 a 150 mil reais. Atualmente, os preços para adquirir lotes de mesma dimensão nesses empreendimentos estão em torno de 110 mil reais no Brisa do Mar II e acima dos 220 mil no Alphapark e Cidadelle Praia do Sul (valores de referência do final do ano de 2017).

Se analisarmos o descompasso entre a precariedade que caracteriza a maior parte da área de estudo no que tange serviços públicos e equipamentos urbanos, o elevado valor dos imóveis de médio e alto padrão e o sucesso de vendas desses empreendimentos - sobretudo nas fases de pré-venda e lançamento - podemos concluir que existe uma demanda real de imóveis nessa área. Contudo identificamos que a garantia de certos parâmetros de vida urbana parece ser condição sine qua non da ocupação recente da rodovia no que se refere aos fluxos promovidos diretamente pelo mercado imobiliário.

${ }^{22}$ Os imóveis construídos também valorizaram bastante no período. No entanto preferimos trabalhar com o valor de terrenos por compreender que quando se trata de construções, outros elementos passam a compor o preço. 
Por outro lado, a multiplicação desses empreendimentos e o contraste entre os recursos que eles disponibilizam para seus moradores e aqueles que são ofertados para a população em geral - esses caracterizados pela escassez de políticas públicas direcionadas ao desenvolvimento da área de estudo parecem sinalizar para a proliferação de enclaves de urbanidade.

\section{CONSIDERAÇÕES FINAIS}

Desenvolvemos esse estudo, sob a perspectiva da ciência geográfica, para compreender as recentes transformações na Rodovia Ilhéus-Olivença (BA-001). Essa área de estudo nos pareceu significativa, por concentrar a maior parte dos principais empreendimentos imobiliários de médio e alto padrão do município apesar da evidente precariedade dos serviços públicos e da escassez de equipamentos urbanos.

Como forma de melhor compreender as transformações em curso revisitamos brevemente o histórico de ocupação desse trecho da rodovia e verificamos que diferentemente da apropriação do espaço que observamos atualmente - em sua maior parte polarizada pelos empreendimentos supracitados - a ocupação histórica dessa área, ainda que até então pouco expressiva, foi fundamentalmente orientada por ações do Estado.

Ao lançamento do empreendimento VOG João de Góes no ano de 2010, que parece ter sinalizado para a demanda por imóveis nessa região, novos projetos se seguiram e hoje somam 15 novos empreendimentos em diversas fases de desenvolvimento. Dentre eles, 12 estão localizados ao sul da Avenida Oduvaldo Evaristo Bacelar e, portanto, estão sujeitos a uma série de limitações que caracterizam a área de estudo; limitações essas que, como vimos, mais a aproximam da realidade rural do que da urbana, como é oficialmente classificada pelo município.

Não obstante as inúmeras dificuldades que viver nessa área impõe, a ampla infraestrutura implementada pela maioria dos novos empreendimentos, o crescente sucesso de vendas e a valorização dos imóveis na área de estudo parece indicar que para parcela significativa da classe média e média alta a proximidade das praias mais procuradas do município e a ideia de uma melhor qualidade de vida compensam a realidade rural que os cerca. 
Mesmo diante da significativa e recente ocupação da Rodovia Ilhéus-Olivença (e a tendência ao aumento de habitantes a curto e médio prazo) não identificamos ações que garantam o acesso e ampliação dos serviços públicos e nem a instalação de equipamentos urbanos para a população em geral. A modesta atuação do poder público no planejamento e gestão dessa área reforça os enclaves de urbanidade pois, na prática, as melhorias infraestruturais que estão sendo implantadas na área - rede de esgoto, iluminação pública, asfaltamento, áreas de lazer - ficam circunscritas aos novos empreendimentos, reafirmando a segregação social e criando oásis de conforto, segurança, lazer e bemviver num universo de precariedade.

Também avaliamos, a tendência de apropriação do espaço pelo mercado imobiliário tende a se intensificar nos próximos anos visto a procura pelos empreendimentos mais recentes - como o VOG Ácqua, por exemplo que se encontra em fase de lançamento e já teve todas as unidades vendidas.

Além disso, nossa observação estruturada das transformações na área de estudo, identificou grandes glebas de localização estratégica que até o final de 2015 não estavam no mercado e que passaram a sinalizar intenção de venda. São pelo menos três novas áreas à venda às margens da Rodovia BA-001 que poderiam abrigar novos empreendimentos de grande porte: a) uma área de aproximadamente $25.000 \mathrm{~m}^{2}$ situada entre o VOG João de Góes e o Cidadelle Praia do Sul (Km 4) b) uma segunda área de aproximadamente $15.000 \mathrm{~m}^{2}$ situada nas proximidades do Alphapark ( $\mathrm{Km} 7$ ), entre o mar e a rodovia e c) uma imensa área de $450.000 \mathrm{~m}^{2}$ localizada a cerca de um quilômetro do distrito de Olivença (Km 14).

\section{REFERÊNCIAS}

ALPHAPARK. Alphapark. [Material de divulgação]. Ilhéus: CICON, Construtorae Incorporadora, 2014.

BAIARDI, Almicar. Subordinação do trabalho ao capital na lavoura cacaueira da Bahia. São Paulo: Hucitec, 1984.

CALDEIRA, Teresa Pires do Rio. Enclaves fortificados: a nova segregação urbana. Novos Estudos, São Paulo, n. 47, p. 155-176, mar. 1997

CHIAPETTI, Jorge. O uso corporativo do território brasileiro e o processo de formação de um espaço derivado: transformações e permanências na Região Cacaueira da Bahia. 2009. 205 f. Tese (Doutorado em Geografia) - Programa de Pós-Graduação em Geografia, Universidade Estadual Paulista, Rio Claro, 2009. 
CICON Construtora e Incorporadora. Dados gerais. Disponível em: www.cicon.com.br. Acesso em: 20 dez. 2016.

CUENCA, Manuel A. Gutiérrez; NAZÁRIO, Cristiano Campos. Importância Econômica e Evolução da Cultura do Cacau no Brasil e na Região dos Tabuleiros Costeiros da Bahia entre 1990 e 2002. Aracaju: Embrapa Tabuleiros Costeiros, 2004.

HENRIQUE, Wendel. Florianópolis/Brasil - A felicidade não tem preço, tem endereço: condomínios, loteamentos e a apropriação da natureza. Scripta Nova: Revista Electrónica de Geografía y Ciencias Sociales, Barcelona, vol. IX, n. 194, p. 01-11, 2005.

IBGE. Cadastro Central de Empresas 2001. Disponível em: http://ibge.gov.br. Acesso em: 04/10/2005.

Produto Interno Bruto dos Municípios 1999-2002. Disponível em: http://ibge.gov.br. Acesso em: 04/10/2005.

Brasil: Microrregiões. Brasil, 2010. 1 cartograma. Sem escala. Disponível em: http://www.ibge.gov.br/home/geociencias/cartogramas/microrregiao.html. Acesso em: 21 mar. 2010.

IBGE Cidades Bahia Ilhéus. Disponível em: http://cidades.ibge.gov.br/xtras/perfil.php?lang=\&codmun=291360. Acesso em: 04/01/2015.

Classificação e caracterização dos espaços rurais e urbanos do Brasil: uma primeira aproximação. Rio de Janeiro, IBGE, 2017.

ILHÉUS. Lei 2.296 de 15 de maio de 1989. Ilhéus: Prefeitura Municipal de Ilhéus, 1989.

Lei Orgânica do Município de Ilhéus. Ilhéus: Câmara Municipal, 1990.

Lei 2.400 de 06 de agosto de 1991. Ilhéus: Prefeitura Municipal de Ilhéus, 1991.

Lei n. 3746 de 09 de outubro de 2015. Ilhéus: Prefeitura Municipal de Ilhéus, 2015.

MIRA, Elson Cedro. Mudança institucional e reconversão produtiva no Sul da Bahia. Ilhéus: Editus, 2015.

NASCimenTO, D. M. C.; RODRIGUEZ, J. M. L.; SILVA, S. C. B. M. Mudanças na ocupação econômica do litoral sul da Bahia: os exemplos de Belmonte e Canavieiras, Bahia. Revista Desenbahia, Salvador, n. 10, p. 07-28, mar. 2009.

NEVES, K. F. T. V. Relação cidade-campo: estudo da produção do conhecimento na ciência geográfica brasileira a partir dos anais dos Encontros Nacionais de Geografia Agrária (ENGA). 2010. 299f. Dissertação [Mestrado em Geografia]. Salvador: Universidade Federal da Bahia: 2010.

NEVES, K. F. T. V. Formação territorial do Sul da Bahia e produção não-convencional do cacau. 2018. 242f. Tese [Doutorado em Geografia Humana]. São Paulo: Universidade de São Paulo, 2018.

NOIA, A.; MIDLEJ, M. M. B. C. \& ROMANO, J. O. A cacauicultura na Região Sul da Bahia: trajetória, crises e perspectivas. In: GOMES, Andréa da Silva; PIRES, Mônica de Moura. Cacauicultura: estrutura produtiva, mercados e perspectivas. Ilhéus: Editus, 2015.

OLIVEIRA, Olga Maria Góes. A expansão urbana da cidade de Ilhéus - BA e a ocupação dos manguezais: o caso do bairro São Domingos. 2008, 205f. Tese (Doutorado em Engenharia Ambiental Urbana) - Escola Politécnica, Universidade Federal da Bahia, Salvador, 01 de abril de 2008.

PEREIRA, Francisco S. R. Mercado imobiliário em médias cidades: estudo da formação, crescimento e influência do mercado de imóveis em Imperatriz-MA. 90f. Dissertação (Mestrado em Administração). Universidade da Amazônia, 2013. 
RAMOS, Jefferson da Silva; NOIA, Angye Cássia. Análise da execução do Programa Minha Casa Minha Vida nos municípios de Ilhéus e Itabuna, Bahia. In: SEMANA DO ECONOMISTA E ENCONTRO DE EGRESSOS. 4., 2014, Ilhéus. Comunicações... Ilhéus: UESC, 2014. p. 01-20.

ROCHA, Lourdes Bertol. A região cacaueira da Bahia - dos coronéis à vassoura-de-bruxa: saga, percepção, representação. Ilhéus: Editus, 2008.

ROSAS, Celbo A. F. A (des)construção da dicotomia rural-urbano no extremo noroeste paulista In: ENCONTRO NACIONAL DE GEOGRAFIA AGRÁRIA, 19., 2009, São Paulo. Anais eletrônicos... São Paulo: USP, 2009. pp. 1-32.

SANTOS, Milton. Metamorfoses do espaço habitado. 6 ed. São Paulo: Editora da Universidade de São Paulo, 2008. 2009. . A natureza do espaço: técnica e tempo, razão e emoção. 4 ed. São Paulo: Editora da Universidade de São Paulo,

SILVA, Bárbara-Christine et. al. Atlas Escolar Bahia: espaço geo-histórico e cultural. 2 ed. João Pessoa: Grafset, 2004.

SPANGHERO, Pedro. Elaboração de materiais cartográficos. Campinas: 2018.

TRINDADE, Gilmar Alves. Aglomeração Itabuna-Ilhéus: Rede urbana regional e interações espaciais. Ilhéus, Editus, 2001.

ZENI, A. F; VISSIRINI, J. \& LEAL, M. PET- Plano Estratégico de Turismo. Ilhéus: GEPET, 2000. 